\title{
CONCEPTUAL FRAMES OF REFERENCE AND THEIR INFLUENCE ON E-COMMERCE SYSTEM DEVELOPMENT
}

\author{
GLEN L. VAN DER VYVER and MICHAEL S. LANE \\ Department of Information Systems, University of Southern Queensland, Australia
}

\begin{abstract}
The complexity and uncertainty that is inherent in the e-commerce environment poses a number of challenges to the development of e-commerce applications. Key stakeholders consistently use heuristics to make sense of the challenges they face. The most pervasive of these heuristics is framing, whereby people rely on a conceptual set to organise their perceptions. This process has some benefits but it can also lead to a narrow approach, ignorance concerning important elements of the decision environment and an absolute reliance on a specialist area of knowledge. This has significant implications for coherence of effort and vision, elements crucial to the success of ecommerce projects. This paper uses a case study, qualitative approach in order to establish whether there is evidence for the operation of the framing heuristic, particularly within the context of risk perception, within a variety of e-commerce system development environments.
\end{abstract}

\section{INTRODUCTION}

E-commerce is without doubt one of the key indicators of the arrival of a new global economy, even a new global society, with new imperatives and new ways of thinking. Those who foresaw the coming revolution just a couple of decades ago did not speak of e-commerce directly but of a business environment characterised by rapid change and paradigm shift (Drucker, 1988; Marchand and Horton, 1986; Peters, 1987). In the new economy, the well-learned and dependable skills, methods and procedures that worked well in the past are becoming obsolete and we only have a

The original version of this chapter was revised: The copyright line was incorrect. This has been corrected. The Erratum to this chapter is available at DOI: 10.1007/978-0-387-35692-1_36 
vague conceptualisation of what will replace them. (Earl, 1997; Gue Henno, 1995)

This paper focuses on the use of the framing heuristic by key stakeholders in the complex and uncertain environment of e-commerce. The paper reports on the potential influence of the framing heuristic when stakeholders attempt to make sense of complex and uncertain e-commerce system development environments and explores the social construction of ecommerce reality. Such an approach will help facilitate and inform strategic management issues in the e-commerce environment.

The paper is structured as follows. First, we discuss the inherent complexity and uncertainty that exists in the e-commerce environment and its impact on the way in which key stakeholders strive to make sense of that environment. Then, we discuss the use of heuristics, particularly the framing heuristic, in situations where there is significant uncertainty and ambiguity. Next, we present and discuss a risk model for e-commerce. Then the research issue is outlined and the research method is described and justified. Next, the potential impact of the framing heuristic within the context of ecommerce system development is investigated in a number of case organisations, and the findings are discussed. Finally, there are some concluding remarks regarding the potential significance and relevance of the framing heuristic in the development of e-commerce systems.

\section{DEALING WITH THE COMPLEXITY AND UNCERTAINTY IMPOSED BY E-COMMERCE}

The cataclysms of the past twelve months in the e-commerce arena, coming as they did on the crest of a wave of unbridled confidence, lend all the more credence to the fundamental premise that the modern economy is more unpredictable and uncertain than ever. There is now a substantial body of evidence which indicates that rational responses become all the more difficult as the levels of uncertainty and ambiguity in social systems become more prevalent (Simon, 1976; Douglas and Wildavsky, 1982; Handy, 1989). The markets of two years ago largely reflect this, based as they were on a frenzy of investment in unknown companies with no track record operating in an uncertain and undefined business environment. Many investors could not envisage the prospect of large-scale corporate failures because they were trapped in a perception environment where they had never seen failure. Most of these people did not rationally plan their investment decisions by attempting to forecast the likelihood of future events. Rather, they were seduced by the irrational belief that the past and present somehow tell us what will happen tomorrow, that today is part of some mysterious pattern 
which may fluctuate slightly tomorrow but whose course to inevitable success is assured.

Not all individuals or corporate cultures are equally imbued with the capacity to manage complex and uncertain environments. (Smart and Vertinsky, 1984; Webber, 1997) Some, indeed, are doomed to failure from the outset as they are inherently incapable of managing uncertainty. Webber (1997) speaks of the 'vision thing', and argues that many professionals today are so overwhelmed by the complexities of the task at hand that they struggle to make informed decisions. They are unable to focus on issues unrelated to their area of expertise. This has profound implications for the development of e-commerce systems where a narrow approach is untenable. e-commerce systems development requires a multidisciplinary, team-based effort. Perhaps more than anything else, it requires vision and a critical mind. It requires people who are prepared to question whether the tried and trusted methods of the past are applicable to the new business context.

\section{USE OF HEURISTICS TO COPE WITH COMPLEXITY AND UNCERTAINTY}

People do not even attempt to deal with all the complexities in any but the most simple of situations. (Simon 1976). They seek to construct a simplified model of the world based upon their values, knowledge and experiences. Central to this process is the use of heuristics, or subconscious mental rules of thumb which allow us to make sense of novel, ambiguous or uncertain problems. These heuristics are essential because they make the incomprehensible comprehensible. That is not to say that that they lead to rationality. It might be better to say that heuristics make us think that we comprehend something. The decisions we make, the conclusions we reach and the explanations we offer are often based on our judgements of the likelihood of uncertain events (Kahnenman \& Tversky 1974). People do not as a matter of course follow the principles of rationality or probability theory when making judgements. Indeed, 'irrational' heuristics often have a pervasive but unconscious influence on the cognitive processes involved in the determination of a course of action.

The operation of cognitive decision structures in uncertain environments was examined and it was concluded that humans need to simplify and structure perceptual materials in order to make sense of their environment (Walsh 1988). This is emphasized succinctly by Walsh (1988):

'Managers routinely confront ill-structured, complex problems that challenge their cognitive capacities. They must meet such challenged with limited 
information-processing capabilities . . . managers construct belief structures that are simplified representations of their worlds. These belief structures are considered indispensable to any decision maker, for without them individuals would be overwhelmed by an information world of staggering complexity'

\section{FRAMING TERMS OF REFERENCE}

A wide variety of heuristics and biases have been identified and much work has been done on their influence on human cognitive and perceptual processes. Enduring problems with this research have included isolating the effect of individual heuristics, measuring the potential for interaction effects and determining the cumulative influence of a variety of heuristics acting in concert. Russo and Shoemaker $(1990,1992)$ address some of these problems when they argue that there exists an overall or higher-level heuristic which they call framing. They argue that people structure decision environments in terms of a conceptual set, using cognitive structures to make sense of the world. These structures are clearly heuristic in nature but Russo and Shoemaker argue that overall conceptual style dominates individual heuristics. Their work builds upon the seminal work of Douglas and Wildavsky (1982) on risk perception.

Risk perception is subjective, based upon conceptual frameworks (Douglas \& Wildavsky, 1982).. The fundamental point of departure is that it is impossible for any individual, corporation or society to ever know the totality of risks that it faces. At a macro level, risk selection is a social process. Thus, people from different cultures might have risk sets that are totally different, where risk set refers to the totality of risks that culture admits into its collective consciousness. At the micro level, risk selection is an individual process, dependant upon the conceptual style of the individual decision maker.

Framing is both very useful and very dangerous (Russo \& Shoemaker 1992). In an increasingly complex world, it is simply impossible to function without conceptual frames of reference. While this process does allow us to function it is also insidious, sometimes leading to wildly inaccurate decisions and even a world concept that is far removed from reality. Often the partial view of the problem which the frame of reference encompasses precludes the identification of the correct course of action, literally forcing an incorrect decision or course of action. Alternatively, outdated rules of thumb may be used or a particular rule of thumb may be applied to an inappropriate situation. 


\section{ROLE OF HEURISTICS AND FRAMING OF TERMS OF REFERENCE ON DECISION MAKING OF KEY STAKEHOLDERS IN E- COMMERCE SYSTEM DEVELOPMENT}

Information Technology professionals are by no means above decision errors (Wiseman 1988). Many companies are constrained by their own culture and unable to make rational decisions about Information Technology. Acting as some companies do within a defunct paradigm, their IT solutions are doomed to failure. Thus, identifying good information systems and potential risks depends upon the conceptual perspective of the people involved, the perspective of the corporate culture, even the mores and values of the society in which the action is situated. E-commerce is an activity whose whole being is permeated with uncertainty and ambiguity. It has a short history and continues to evolve rapidly. Relatively few rules or guidelines exist, which is not surprising as the encompassing paradigm is itself fluid. Although an increasing volume of research is devoted to ecommerce systems development, e-commerce risk management and the like, we are not sure that this work has made much impact at the coalface.

We are concerned here with the way process, problem areas, potential risks and even the meaning of e-commerce are conceptualised by various participants in the construction of e-commerce technologies. Cognitive theory would suggest that there could be significant differences in perception between companies and industries but, more important for our purposes, even between people participating in the same project. We do not speak here of conflicting viewpoints or corporate politics but of different conceptual frameworks. Thus, two people working on the same project may not even assign the same meaning to the term e-commerce. They may very well fall back in terms of what they know, whether that is a well-worn and wholly inappropriate paradigm or a narrow reliance on an expert field of knowledge. Surely, this would be a recipe for failure.

\section{E-COMMERCE RISK MODEL}

APRA Insight (2001) identified that electronic commerce poses a number of potential risks such as operational risk, reputational risk, outsourcing risk, strategic risk, legal risks, increased liquidity risk and narrowing of margins (see figure 1 Dimensions of risk in E-Commerce). A discussion of these different types of e-commerce risk follows. 


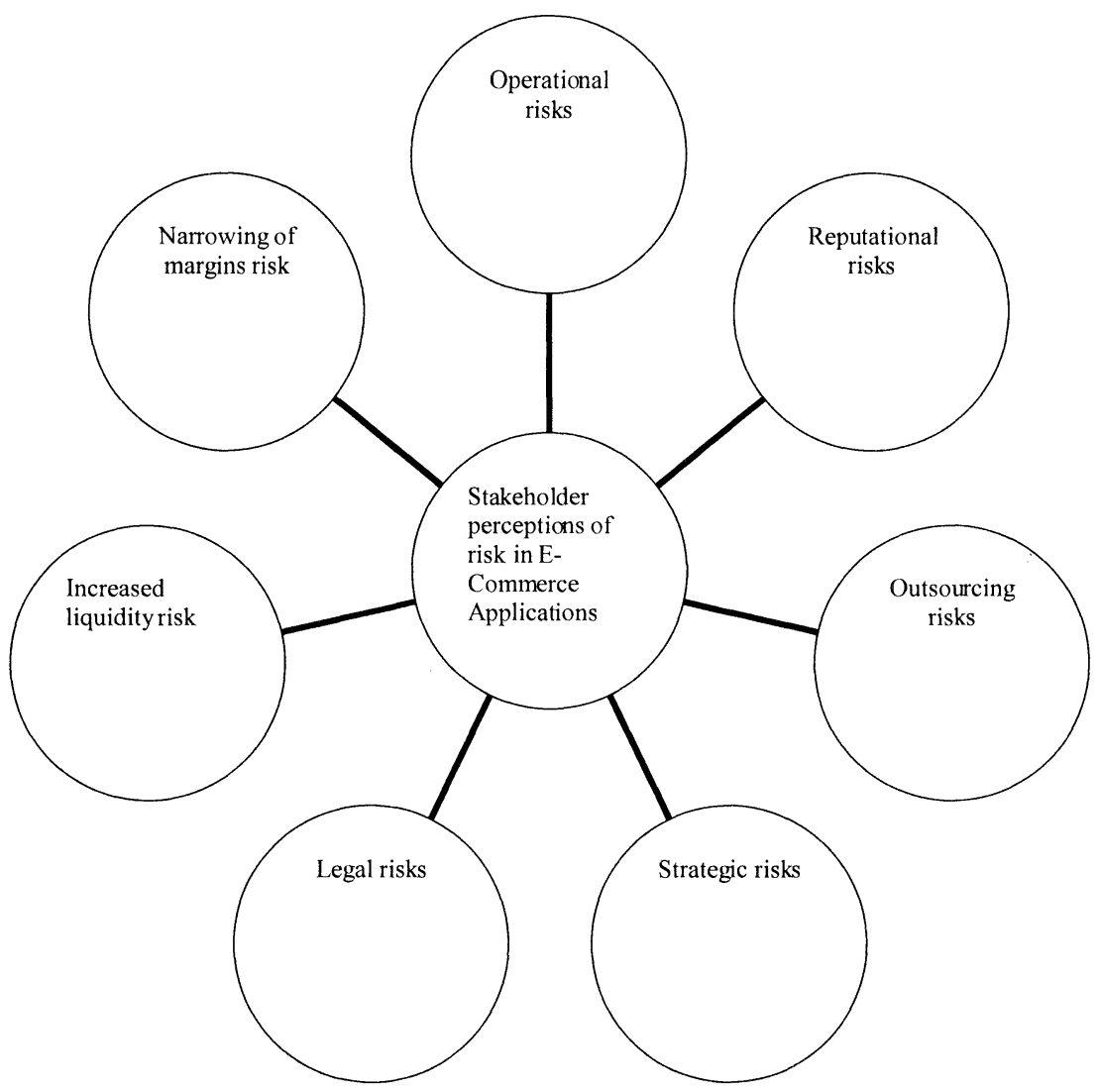

Figure1. Different dimensions of risk in E-Commerce System development

Source: APRA Insight 2001

Electronic commerce is highly dependent on system reliability and integrity and, as a result, highly vulnerable to operational risk. In particular, security raises significant concerns. By its very nature, the Web is very public and anything published is technically accessible to anyone. Reputation risk implies that there is also an expectation from the public that a web site is available 24X7. While there are considerable benefits from outsourcing, increased reliance on third parties for provision of services, products and infrastructure also increases risk. Strategic risk arises from the pace of innovation in electronic commerce and the considerable costs 
involved keeping abreast of new technologies. The rights and obligations of various parties to an electronic transaction can be unclear and open to legal challenge, with existing laws and regulations not keeping pace with electronic commerce developments. Increased liquidity risk may arise from the ability to rapidly transfer funds between accounts and institutions resulting in a virtual bank run on funds. The openness of the Internet creates a dilemma in that customers can easily compare products and services offered by institutions resulting in a narrowing of profits. Many of these risks are applicable to any organization conducting electronic commerce using a web site.

This dimensions of risk model was used to assess the perceptual differences in key stakeholders in relation to risk in e-commerce systems. We argue in this paper that perceptual differences in key stakeholders frames of reference has significant implications for the development of e-commerce systems This model was developed within a particular context, the financial services industry. It is interesting to note that most of the potential risks seem to apply equally to e-commerce in general. The model focuses on a relatively few risks at a high level. Clearly, there are many other potential risks but it does seem possible to make some sense of all the factors as a collectivity. Yet, it is clear that each risk factor could spawn many subcategories. When this happens, we believe that people will begin focusing on a few areas, or even one, because there is a limit to the number of risks we are able to think about at any given time.

\section{RESEARCH ISSUE AND METHOD}

This study was designed to investigate the use of the framing heuristic in the decision making processes of key stakeholders in the e-commerce system development process. E-commerce systems are becoming increasingly complex and sophisticated with many systems supporting extensive information, communication, distribution and transaction capabilities (Angehrn \& Meyer 1997). As a result the key stakeholders in e-commerce system development are faced with making decisions in a complex and uncertain environment.

Individually, key stakeholders will use differing sets of heuristics and framing of terms of reference in their decision making in relation to ecommerce system development. This may result in misalignment of the business strategy and objectives of an e-commerce system and the increased risk profile and likely failure of these systems. The management of potential differences in the terms of references of key stakeholders in e-commerce 
systems will reduce the risk and potential failure associated with such types of systems.

A qualitative approach was deemed appropriate as this line of research is in the exploratory stage (Galliers 1994, Yin 1994). A case study method was used as it allows the researchers to investigate in-depth the phenomena of interest, the research issue in a real life context (Gable 1994). There is also a lack of empirical research on the potential differential effects of heuristics and framing in the e-commerce system development process. In the first phase of this research, data collection involved analysis of the perceived risk of e-commerce in four case organisations that have been involved in developing e-commerce systems. These case organisations were purposely chosen because two of the cases are banking institutions that followed a traditional informed path to e-commerce system development. The other two case organisations were chosen because they are new Internet start up companies with no background or tradition in information systems development. A number of key stakeholders were interviewed from each case organisation. The heuristics and frames of reference that they used in their decision making in relation to the various levels of risk inherent in the e-commerce system development process were compared. We will explore the following:

1. Do people perceive e-commerce systems development as uncertain and / or risky. Are there clear intra-organisational and / or inter-organisational differences.

2. Do people from different areas of the corporation perceive e-commerce in different ways.

3. Do people from corporations operating in different sectors of the economy perceive e-commerce in different ways.

4. What appears to be the most significant characteristics of the frame/s of reference people use to conceptualise the method, procedures and problems associated with e-commerce system development. In particular, we are interested to determine whether people are attempting to understand e-commerce in terms of frameworks that are no longer valid.

\section{OVERVIEW OF CASE ORGANISATIONS}

Two of the case organisations that were chosen for this study are large financial institutions that have relatively sophisticated Internet banking presences. These case organisations have Internet banking sites which are an aggregate of organisation content and banking applications. The ongoing development of these Internet banking sites involves a diversity of key stakeholders both internal and external to the case organisations. The 
migration of traditional banking and relevant banking content to e-commerce environment poses many challenges in the ongoing development of ecommerce systems. The other two case organisations chosen for this study were involved selling products online. These case organisations are new Internet start-up companies with extensive previous history in the traditional way of business but no previous history in information systems development. Their web sites were designed to be largely functional sites that facilitated the purchase of products online.

Case A is a medium sized financial institution that is based in Toowoomba. The organization has been in existence for over 100 years and currently employs over 1000 people in its financial institution banking operations. It has had a web presence since 1997, and Internet banking capability since 1998. The general IT manager, marketing manager, IT operations manager, managing director of a Queensland based software company that builds and hosts Internet banking solutions for financial institutions and the Queensland state manager of a regulatory authority that monitors financial institution operations including Internet banking were interviewed.

Case B is large financial institution which has branches nationwide. The organization has been in existence since 1909 and currently employs over 7,700 people nationally. It has had a web presence since 1996 and has had Internet banking capability since 1998. The content manager, two business analysts, the Internet banking project manager, and Internet architecture manager were interviewed.

Case $\mathrm{C}$ is an online pharmacy and has been an operational entity for little over 18 months. Case C's web site is primarily concerned with the sale of pharmaceutical products online. Retail pharmacy is a highly regulated industry, hence there were considerable constraints on the operation of online pharmacy. The Manager Director, Customer Relationship Management Employee and the External Web Developer were interviewed.

Case D is a pure Internet organization. The company is based in Armidale and operates a florist relay network. It was one of the first Internet based Florist Relay Networks to be established in the world. The organization has had a operational web site which supports secure transactions over the Internet since 1994. The organization employs about 10 people full time with three employees involved full time with developing and maintaining the web site. A fourth employee is involved in web site maintenance and enhancement on a casual basis on two to three days a week. The other employees are involved supporting in the call centre, order processing and fulfillment. The organization has annual turnover of 10 
million dollars per annum. The chief executive, marketing manager and the external web developer were interviewed.

\section{FINDINGS AND DISCUSSION}

The risk perceptions of key stakeholders in the four case organisations were analysed on the basis of the dimensions of risk in e-commerce model presented in figure 1. The following tables 1, 2, 3 and 4 present the summarised findings in each relation to each case organisation and research objectives of this study. Each case organisation will now be discussed in relation to the findings. A number of direct quotations are included to highlight the different frames of references that key stakeholders use to construct their perception of risk in the development of e-commerce systems.

\begin{tabular}{|c|c|c|c|c|c|c|c|}
\hline Case A & $\begin{array}{l}\text { Operatio- } \\
\text { nal } \\
\text { Risk }\end{array}$ & $\begin{array}{l}\text { Repu- } \\
\text { tational } \\
\text { risk } \\
\end{array}$ & $\begin{array}{l}\text { Outsour- } \\
\text { cing } \\
\text { risk }\end{array}$ & $\begin{array}{l}\text { Strategic } \\
\text { risk }\end{array}$ & $\begin{array}{l}\text { Legal } \\
\text { risk }\end{array}$ & $\begin{array}{l}\text { Increasing } \\
\text { liquidity } \\
\text { Risk } \\
\end{array}$ & $\begin{array}{l}\text { Narrowing of } \\
\text { margins } \\
\text { risk }\end{array}$ \\
\hline $\begin{array}{l}\text { Market } \\
\text { ing } \\
\text { manag } \\
\text { er }\end{array}$ & $\begin{array}{l}\text { Acknow- } \\
\text { ledged to } \\
\text { some } \\
\text { extent }\end{array}$ & $\begin{array}{l}\text { Very } \\
\text { important }\end{array}$ & $\begin{array}{l}\text { Not } \\
\text { acknow- } \\
\text { ledged }\end{array}$ & $\begin{array}{l}\text { Acknow- } \\
\text { ledged to } \\
\text { some } \\
\text { extent }\end{array}$ & $\begin{array}{l}\text { Very } \\
\text { import } \\
\text { ant }\end{array}$ & $\begin{array}{l}\text { No } \\
\text { acknowledged }\end{array}$ & $\begin{array}{l}\text { Not } \\
\text { acknowledged }\end{array}$ \\
\hline $\mathrm{CIO}$ & $\begin{array}{l}\text { Very } \\
\text { important }\end{array}$ & $\begin{array}{l}\text { Very } \\
\text { important }\end{array}$ & $\begin{array}{l}\text { Acknow } \\
\text { ledged } \\
\text { to some } \\
\text { extent }\end{array}$ & $\begin{array}{l}\text { Very } \\
\text { important }\end{array}$ & $\begin{array}{l}\text { Very } \\
\text { import } \\
\text { ant }\end{array}$ & $\begin{array}{l}\text { Not } \\
\text { acknowledged }\end{array}$ & $\begin{array}{l}\text { Not } \\
\text { acknowledged }\end{array}$ \\
\hline $\begin{array}{l}\text { IT } \\
\text { operati } \\
\text { ons } \\
\text { manag } \\
\text { er } \\
\end{array}$ & $\begin{array}{l}\text { Very } \\
\text { important }\end{array}$ & $\begin{array}{l}\text { Very } \\
\text { important }\end{array}$ & $\begin{array}{l}\text { Not } \\
\text { acknow- } \\
\text { ledged }\end{array}$ & $\begin{array}{l}\text { Acknow- } \\
\text { ledged to } \\
\text { some } \\
\text { extent }\end{array}$ & $\begin{array}{l}\text { Impor } \\
\text { tant }\end{array}$ & $\begin{array}{l}\text { Not } \\
\text { acknowledged }\end{array}$ & $\begin{array}{l}\text { Not } \\
\text { acknowledged }\end{array}$ \\
\hline $\begin{array}{l}\text { Extern } \\
\text { al } \\
\text { system } \\
\text { develo } \\
\text { per } \\
\text { (CEO) }\end{array}$ & $\begin{array}{l}\text { Very } \\
\text { important }\end{array}$ & Important & $\begin{array}{l}\text { Not } \\
\text { acknow- } \\
\text { ledged }\end{array}$ & $\begin{array}{l}\text { Acknow- } \\
\text { ledged to } \\
\text { some } \\
\text { extent }\end{array}$ & $\begin{array}{l}\text { Impor } \\
\text { tant }\end{array}$ & $\begin{array}{l}\text { Not } \\
\text { acknowledged }\end{array}$ & $\begin{array}{l}\text { Not } \\
\text { acknowledged }\end{array}$ \\
\hline $\begin{array}{l}\text { Regula } \\
\text {-tory } \\
\text { autho- } \\
\text { rity } \\
\text { state } \\
\text { man- } \\
\text { ager }\end{array}$ & $\begin{array}{l}\text { Very } \\
\text { important }\end{array}$ & $\begin{array}{l}\text { Very } \\
\text { important }\end{array}$ & $\begin{array}{l}\text { Import- } \\
\text { ant }\end{array}$ & Important & $\begin{array}{l}\text { Very } \\
\text { import } \\
\text { ant }\end{array}$ & Important & Important \\
\hline
\end{tabular}

Table 1. Summary of Case A - Key stakeholder perceptions of risk in relation to E-Commerce 
In Case A, operational risk was considered important by most of the key stakeholders as the e-commerce development team was small and consisted of both management and technical people. This meant that all of the key stakeholders interviewed were very informed about all of the key issues in relation to Internet banking. The following comment by IT operations manager emphasises that Case A were a small team and communicated well in regard to e-commerce system development.

"Yes a reasonably small group of people generally speaking. We're of common mind and therefore the politics of different peoples views don't necessarily have a ...impact on where we're going" (A3:T314:316).

Reputational risk was considered important by all of the key stakeholders in Case A. They were acutely aware of the consequences of a security breach of their Internet banking systems on the reputation of Case A and on the confidence of their mutual membership. The following comment by the CIO emphasises the importance of reputational risk and the potential impact of a security breach on Case A's incredibility.

"Absolutely, you have a security breach as I said, you pack it up and put it in a box because nobody will us it. It's paramount. I'm just" (A2:T182:183).

Outsourcing was not acknowledged by Case A key stakeholders as being a serious risk. This was not surprising as outsourcing was a significant part of their Internet strategy and rather was seen as a way to compete with the big players in the Australian banking industry. The following comment by the CIO emphasises outsourcing was a critical component of Case A's approach to Internet banking.

"Now going forward we can't do everything in house. This takes up twenty percent of Al's time, it takes up thirty percent, third of my time, its growing, I don't have web designer, I don't have a in house resource.

One of the key stakeholders interviewed was the developer and provider of their Internet banking system. This stakeholder emphasised that they had to reach strict requirements of the banking regulatory authorities such as Australian Prudential Regulatory Authority (APRA). The state manager of APRA reiterated that part of its role was monitor and regulate Internet banking solutions providers. In fact, Case A's strategy to counter the strategic risks imposed by the e-commerce environment was to rely heavily on outsourcing to provide Internet banking solutions. The legal risks were apparent to all of the key stakeholders and it is an issue that has to be dealt within the banking industry. Therefore it is merely a case of ensuring that necessity legal requirements of banking are dealt with in the e-commerce environment and that adequate checks and balances are put in place to ensure that this happens. Not surprisingly, increased liquidity risk of Internet 
banking was considered an important issue by the state manager from the banking regulatory authority in general terms. But this may not be an issue for Case A given that it is a mutual society and its membership is regionally focused. Narrowing of margins was acknowledged to some extent by the key stakeholders but since the primary Internet banking strategy was not cost containment and migration of membership to Internet banking, it was not a major concern.. The following comment emphasises that narrowing of margins was not a concern and that Case A's main focus was on providing value and service to its mutual members.

"My perspective, is customer service, customer choice if we can make banking easier or user friendly that's costly then we're providing value to the. membership. Everything we do is about providing value to our membership" (A2:T734:737).

\begin{tabular}{|c|c|c|c|c|c|c|c|}
\hline Case B & $\begin{array}{l}\text { Opera- } \\
\text { tional } \\
\text { risk }\end{array}$ & $\begin{array}{l}\text { Reputa- } \\
\text { tional risk }\end{array}$ & $\begin{array}{l}\text { Outsour- } \\
\text { cing risk }\end{array}$ & $\begin{array}{l}\text { Strategic } \\
\text { risk }\end{array}$ & $\begin{array}{l}\text { Legal } \\
\text { risk }\end{array}$ & $\begin{array}{l}\text { Increa- } \\
\text { sed } \\
\text { liquidity } \\
\text { risk }\end{array}$ & $\begin{array}{l}\text { Narrow- } \\
\text { ing of } \\
\text { margins } \\
\text { risk }\end{array}$ \\
\hline $\begin{array}{l}\text { Content } \\
\text { Manager }\end{array}$ & $\begin{array}{l}\text { Acknow- } \\
\text { ledged to } \\
\text { some } \\
\text { extent }\end{array}$ & Important & $\begin{array}{l}\text { Not } \\
\text { acknow- } \\
\text { ledged }\end{array}$ & Important & Important & $\begin{array}{l}\text { Not } \\
\text { acknow- } \\
\text { ledged }\end{array}$ & $\begin{array}{l}\text { Not } \\
\text { acknow- } \\
\text { ledged }\end{array}$ \\
\hline $\begin{array}{l}\text { Business } \\
\text { Analyst } \\
\text { for EC } \\
\text { projects }\end{array}$ & $\begin{array}{l}\text { Very } \\
\text { important }\end{array}$ & $\begin{array}{l}\text { Very } \\
\text { important }\end{array}$ & $\begin{array}{l}\text { Not } \\
\text { acknow- } \\
\text { ledged }\end{array}$ & $\begin{array}{l}\text { Very } \\
\text { important }\end{array}$ & $\begin{array}{l}\text { Very } \\
\text { important }\end{array}$ & $\begin{array}{l}\text { Not } \\
\text { acknow- } \\
\text { ledged }\end{array}$ & $\begin{array}{l}\text { Import- } \\
\text { ant }\end{array}$ \\
\hline $\begin{array}{l}\text { Business } \\
\text { Analyst } \\
\text { for EC } \\
\text { Projects }\end{array}$ & $\begin{array}{l}\text { Acknow- } \\
\text { ledged to } \\
\text { some } \\
\text { extent }\end{array}$ & Important & $\begin{array}{l}\text { Acknow- } \\
\text { ledged to } \\
\text { some extent }\end{array}$ & $\begin{array}{l}\text { Acknow- } \\
\text { ledged to } \\
\text { some } \\
\text { extent }\end{array}$ & Important & $\begin{array}{l}\text { Not } \\
\text { acknow- } \\
\text { ledged }\end{array}$ & $\begin{array}{l}\text { Import- } \\
\text { ant }\end{array}$ \\
\hline $\begin{array}{l}\text { Web site } \\
\text { project } \\
\text { manager }\end{array}$ & $\begin{array}{l}\text { Acknow- } \\
\text { ledged to } \\
\text { some } \\
\text { extent }\end{array}$ & $\begin{array}{l}\text { Acknow- } \\
\text { ledged to } \\
\text { some extent }\end{array}$ & $\begin{array}{l}\text { Not } \\
\text { acknow- } \\
\text { ledged }\end{array}$ & $\begin{array}{l}\text { Acknow- } \\
\text { ledged to } \\
\text { some } \\
\text { extent }\end{array}$ & $\begin{array}{l}\text { Acknow- } \\
\text { ledged to } \\
\text { some } \\
\text { extent }\end{array}$ & $\begin{array}{l}\text { Not } \\
\text { acknow- } \\
\text { ledged }\end{array}$ & $\begin{array}{l}\text { Not } \\
\text { acknow- } \\
\text { ledged }\end{array}$ \\
\hline $\begin{array}{l}\text { Web } \\
\text { infra- } \\
\text { structure } \\
\text { manager }\end{array}$ & $\begin{array}{l}\text { Very } \\
\text { important }\end{array}$ & $\begin{array}{l}\text { Acknow- } \\
\text { ledged to } \\
\text { some extent }\end{array}$ & $\begin{array}{l}\text { Not } \\
\text { acknow- } \\
\text { ledged }\end{array}$ & Important & $\begin{array}{l}\text { Acknow- } \\
\text { ledged to } \\
\text { some } \\
\text { extent }\end{array}$ & $\begin{array}{l}\text { Not } \\
\text { acknow- } \\
\text { ledged }\end{array}$ & $\begin{array}{l}\text { Not } \\
\text { acknow- } \\
\text { ledged }\end{array}$ \\
\hline
\end{tabular}

Table 2. Summary of Case B:

- Key stakeholder perceptions of risk in relation to E-Commerce

For Case B, two stakeholders that emphasised operational risk was very important had significant hands on experience in developing and maintaining e-commerce systems since the beginning of the commercialisation of the Internet. Web infrastructure manager have been involved Internet banking since its inception in Australia in 1996 while the 
Business analyst have been involved in setting up a number of Internet start up companies prior to working for Case B. Reputational risk was considered important by a number of the key stakeholders in Case B and this was no doubt influenced by the communication of Case B's e-commerce strategy ,Best Bank' to all of its employees. The following comment by the content manager emphasize Case B stakeholders perceptions of reputational risk were influenced by Case B's Internet banking strategy Best bank strategy implied a strong element of reputational risk. As part of the Best Bank strategy, Case B needed to be seen to be seen as being a leader in Internet banking in Australian market place.

"Because most of the projects that we are doing at the moment come under the umbrella of BEST bank, all the projects do so we have our own methodologies but there is also a best bank method" (B1:T1030:1032).

The following comment by the e-commerce business analyst indicates professional experience also influences perceptions of reputational risk.

"I think its huge, I think that the reputations that people get with web sites both good and bad is huge and it will become more so more and more companies will be judged by the standard of their web presence" (B2:T163:166).

Not many of the key stakeholders interviewed were acutely aware of the potential risk associated with outsourcing e-commerce system development in e-commerce. It should also be said that Case B had countered this risk to some extent as most of its e-commerce system development was in house and it have acquired a number of firms that were involved in specialised Ecommerce system development such secure payment gateway.. External developers were also required to follow e-commerce system development standards set in place by Case B. The following comment by e-commerce business analyst B3 emphasises how Case B handled the risks associated with outsourcing.

"Yeah when external companies do web development obviously we have to communicate in the internal business unit to make sure what is delivered by the external companies up to our internal standards" (B3:T202:206).

The perception of outsourcing risk was guided by in house development procedures that required external developers to meet Case B's IS development standards. It is also maybe true that the very procedures that deal with outsourced development may also reinforce a sense of over confidence in relation to the potential risks of outsourcing E-Commerce system development.

Strategic risk associated with the e-commerce environment was also acknowledged by a number of the key stakeholders due to their extensive experience in developing e-commerce systems from concept through to 
product. The following comment by the web infrastructure manager indicates a level of confidence from a long involvement in e-commerce.

"Firstly I have got a technical background and I have been involved with ecommerce Internet in particular for the past ten years. From the beginning then when the Web took off in Australia" (B5:T7:9).

Not surprisingly legal risks presented by the e-commerce environment were well understood by all of the key stakeholders as legal risks transcend across traditional and electronic banking. The potential of increased liquidity in Internet banking was not considered an important issue by any of the key stakeholders in Case B but regulatory bodies are concerned about the potential for Internet banking to facilitate a run on a banking institute's cash reserves. Obviously, checks should be in place in Internet banking systems that alert organisations if such a situation is arising. Narrowing of margins was acknowledged as being important. A number of the key stakeholders had realised the benefits of Internet banking may be offset by the significant costs of developing and maintaining Internet banking and the need to retain traditional banking infrastructure. The following comment by E-Commerce business analyst emphasises that cost savings of Internet banking may be misleading.

"We replaced three staff down in lending services so that's great yet you hired one web developer, yes that's three to one No No those three people cost $\$ 90,000$ your web developer costs $\$ 120,000$ you are actually $\$ 30,000$ behind now no one is doing that maths so I think it is a bit of misnomer that the fact that it reduces costs when we talk about reduced costs what we do we talk about replacing people that what the banks seem to be concerned about, I think that there " (B2:T177:183).

\begin{tabular}{|l|l|l|l|l|l|l|l|}
\hline Case C & $\begin{array}{l}\text { Opera- } \\
\text { tional } \\
\text { risk }\end{array}$ & $\begin{array}{l}\text { Reputa- } \\
\text { tional } \\
\text { risk }\end{array}$ & $\begin{array}{l}\text { Out- } \\
\text { sourcing } \\
\text { risk }\end{array}$ & $\begin{array}{l}\text { Strategic } \\
\text { risk }\end{array}$ & $\begin{array}{l}\text { Legal } \\
\text { risk }\end{array}$ & $\begin{array}{l}\text { Liquidity } \\
\text { risk }\end{array}$ & $\begin{array}{l}\text { Narrowing } \\
\text { of margins } \\
\text { risk }\end{array}$ \\
\hline $\begin{array}{l}\text { Mana- } \\
\text { ging } \\
\text { Director }\end{array}$ & $\begin{array}{l}\text { Very } \\
\text { im- } \\
\text { portant }\end{array}$ & $\begin{array}{l}\text { Very } \\
\text { important }\end{array}$ & Important & $\begin{array}{l}\text { Very } \\
\text { important }\end{array}$ & $\begin{array}{l}\text { Very } \\
\text { im- } \\
\text { portant }\end{array}$ & $\begin{array}{l}\text { Not } \\
\text { applicable }\end{array}$ & $\begin{array}{l}\text { Very } \\
\text { important }\end{array}$ \\
\hline $\begin{array}{l}\text { Cust- } \\
\text { omer } \\
\text { relation- } \\
\text { ship } \\
\text { manager }\end{array}$ & $\begin{array}{l}\text { Im- } \\
\text { portant }\end{array}$ & $\begin{array}{l}\text { Acknow- } \\
\text { ledged to } \\
\text { some } \\
\text { extent }\end{array}$ & $\begin{array}{l}\text { Not } \\
\text { acknow- } \\
\text { ledged }\end{array}$ & $\begin{array}{l}\text { Very } \\
\text { important }\end{array}$ & $\begin{array}{l}\text { Im- } \\
\text { portant }\end{array}$ & $\begin{array}{l}\text { Not } \\
\text { applicable }\end{array}$ & $\begin{array}{l}\text { Not } \\
\text { acknow- } \\
\text { ledged }\end{array}$ \\
\hline $\begin{array}{l}\text { External } \\
\text { web } \\
\text { deve- } \\
\text { loper }\end{array}$ & $\begin{array}{l}\text { Im- } \\
\text { portant }\end{array}$ & Important & $\begin{array}{l}\text { Not } \\
\text { acknow- } \\
\text { ledged }\end{array}$ & $\begin{array}{l}\text { Not } \\
\text { acknow- } \\
\text { ledged }\end{array}$ & $\begin{array}{l}\text { Im- } \\
\text { portant }\end{array}$ & $\begin{array}{l}\text { Not } \\
\text { applicable }\end{array}$ & $\begin{array}{l}\text { Not } \\
\text { acknow- } \\
\text { ledged }\end{array}$ \\
\hline
\end{tabular}

Table 3. Summary of Case C:

- Key stakeholder perceptions of risk in relation to E-Commerce 
For case $\mathrm{C}$, operational risk was a key issue for the managing director and external web developer. The managing director was aware that a successful E-Commerce site needed to be reliable, efficient and easy to use. The external web developer was also aware of the importance of a web site that was operationally functional and facilitated the online purchase of pharmaceutical goods. The following comment by the external web developer indicates the importance of having a viable operational ECommerce site.

" There's a lot of factors - there's money and then there's I guess, your marketing,
the effectiveness of your marketing, how well you target your users, and on the
technical side how well it works, how quickly the users get the information they
want. You know, how intuitive is the interface. I mean you want to make it
intuitive for an e-Commerce site. They're coming in - they're either going to be
just having a general browse and then they might find something that they want
to buy or they're coming in to purchase something specifically. So you've got to
cater for them and you've got to get them through seamlessly. You can't confuse
them - there can't ever be a stage where they're going 'where do I go next'. It's "
(C2:T549:558).

Case $\mathrm{C}$ operated in a highly regulated industry, retail pharmacy. The managing director was highly aware that the online reputation of Case $\mathrm{C}$ was of paramount importance to its survival and acceptance in the industry.. There were a number of government and industry regulatory bodies that could easily shut down Case C's E-Commerce site at a moments notice if it was seen to be acting illegally or unethically online. The following comment by manager director indicates an awareness of the reputational risks associated with an online pharmacy.

"The other thing you should be looking at is - no other Internet website with pharmacy in Australia at the moment does this. We're the only one who does it. So I've actually had the Pharmacy Guild out here watching me and the particular reason I did that was I wanted to show them what we do here, because we're all being cast at the moment in the same pot" (C1:T115:120).

Reputational risk was less of an issue to the external web developer who was more concerned with delivering technical solutions to meet the managing director's requirements. The customer relationship manager was aware of the importance dealing promptly and courteously with customer orders and inquiries, and that customers needed to be ensured that shopping online was safe and secure. The managing director was aware of the consequences of the outsourcing of the Case C's E-Commerce site and appropriate legal documents have been drawn up to protect the intellectual property and business assets of Case $\mathrm{C}$. 
"C3... Development Company is what they're called - the programmers. And document that was drawn up by the legals - ensured that the possession of intellectual property.....and who owned everything and we own the domain name, we own the information, we own the rights to anything that was created by us and to actually build the site. So that was a very important document - about 30 pages. " (B1:T1422:1477).

Outsourcing was not acknowledged as an issue by the external web developer and the customer relationship manager. The external web developer was providing the outsourced development and maintenance of Case C's E-Commerce site while the customer relationship manager was not actively involved in the development process. On the other hand, the managing director was aware that outsourcing posed legal risks concerning ownership of the intellectual property. The strategic risks of E-Commerce system development were considered to be very important by the managing director and the external web developer. There needed to be a balance between providing the necessary sophistication in an E-Commerce site and the resource limitations of a small organisation like Case C. Again, this was not an immediate concern of the customer relationship manager in relation her perception of risk in E-Commerce. Legal risks were considered important by all of the key stakeholders as retail pharmacy is a highly regulated industry and there are significant legal requirements that need to met when selling pharmaceutical goods. The following comment by the managing director emphasises the importance of addressing legal risks that arise from selling retail pharmaceutical goods online.

"And you're right; liability is a big issue. You know in our game if you give out the wrong, like if you're selling beer and you give out the wrong type of beer who cares! But here if you give out the wrong drug - the implications. So you're correct - the liability on our side is massive and cost me a lot of money to address those, through lawyers but we feel confident with what we've covered" (C1:T95:101).

Increased liquidity was not applicable to this case. Narrowing of margins was acknowledged by the managing director and was actually one of the reasons that had prompted the managing director to consider the viability of an online pharmacy. Traditional retail pharmacy was actually facing a narrowing of margins due to increased competition from the supermarket chains and looming threat of deregulation of the industry.

In Case D, the operational risks associated with an E-Commerce site were acknowledged by the managing director and by the marketing/customer relationship manager and the external web developer to a lesser extent. The following comments by the managing director that he considered a viable operational site needed to attract users through search engines. 


\begin{tabular}{|l|l|l|l|l|l|l|l|}
\hline Case D & $\begin{array}{l}\text { Operational } \\
\text { risk }\end{array}$ & $\begin{array}{l}\text { Repu- } \\
\text { tational } \\
\text { risk }\end{array}$ & $\begin{array}{l}\text { Out- } \\
\text { sourcing } \\
\text { risk }\end{array}$ & $\begin{array}{l}\text { Strategic } \\
\text { risk }\end{array}$ & Legal risk & $\begin{array}{l}\text { Liqui- } \\
\text { dity } \\
\text { risk }\end{array}$ & $\begin{array}{l}\text { Narrow- } \\
\text { ing of } \\
\text { margins } \\
\text { risk }\end{array}$ \\
\hline $\begin{array}{l}\text { Managing } \\
\text { Director }\end{array}$ & $\begin{array}{l}\text { Very } \\
\text { important }\end{array}$ & $\begin{array}{l}\text { Very } \\
\text { important }\end{array}$ & Important & $\begin{array}{l}\text { Very } \\
\text { important }\end{array}$ & $\begin{array}{l}\text { Very } \\
\text { important }\end{array}$ & $\begin{array}{l}\text { Not } \\
\text { appli- } \\
\text { cable }\end{array}$ & Important \\
\hline $\begin{array}{l}\text { Marketing/ } \\
\text { Customer } \\
\text { relation- } \\
\text { ship } \\
\text { manager }\end{array}$ & $\begin{array}{l}\text { Acknow- } \\
\text { ledged to } \\
\text { some extent }\end{array}$ & Important & $\begin{array}{l}\text { Not } \\
\text { acknow- } \\
\text { ledged }\end{array}$ & $\begin{array}{l}\text { Acknow- } \\
\text { ledged to } \\
\text { some } \\
\text { extent }\end{array}$ & Important & $\begin{array}{l}\text { Not } \\
\text { appli- } \\
\text { cable }\end{array}$ & $\begin{array}{l}\text { Not } \\
\text { acknow- } \\
\text { ledged }\end{array}$ \\
\hline $\begin{array}{l}\text { External } \\
\text { web } \\
\text { developer }\end{array}$ & $\begin{array}{l}\text { Very } \\
\text { important }\end{array}$ & Important & $\begin{array}{l}\text { Not } \\
\text { acknow- } \\
\text { ledged }\end{array}$ & $\begin{array}{l}\text { Acknow- } \\
\text { ledged to } \\
\text { some } \\
\text { extent }\end{array}$ & $\begin{array}{l}\text { Not } \\
\text { acknow- } \\
\text { ledged }\end{array}$ & $\begin{array}{l}\text { Not } \\
\text { appli- } \\
\text { cable }\end{array}$ & $\begin{array}{l}\text { Not } \\
\text { acknow- } \\
\text { ledged }\end{array}$ \\
\hline
\end{tabular}

Table 4. Summary of Case D:

- Key stakeholder perceptions of risk in relation to E-Commerce

"That also means that your website needs to designed to be friendly to the search engines not the Yahoos not the directories but the Alta Vistas who actually visit you site and crawl over it. Now you are probably familiar with Hallway and Doorway technology You'll find that less than half about a third of our website is actually visible to you two thirds of it is not see by the consumer it is only seen by the search engines. That is not pages that is two thirds of the pages that we have are what we call doorway pages they are designed to get into a search engine by a certain criteria so if you type in Flowers Toowoomba we would be trying very hard" (D1:T220:227).

The managing director also considered that the site should be functional and facilitate purchasing online.

"It is quite important that it is functional and processes you quickly in my opinion. So what we want to do is people have arrived at a website they want to consume because that is why they are going there. We see our job as getting to the consuming page as fast as possible. So we would say the speed, high speed plenty of. speed is I think more critical than anything. Product range is not too much because too much product range confuses them and the other thing that you need to establish very quickly on your web site is creditability - why should I deal with this " (D1:T342:350).

The external web developer was employed on a part time basis. The managing director was heavily involved in any new development of the ECommerce while the marketing/customer relationship manager and external web developer were largely involved maintenance work. Reputational risk was considered important by all of the key stakeholders as Case D was 
dependent on the commercial viability of its E-Commerce site. This was particularly evident in Case D's approach to customer relationship management. The philosophy was that the customer is always right and that any florist in the relay network that behaved unethically towards the retail customers was given one warning only. Outsourcing was only considered an issue by the manager director in that he was reliant on the external web developer to maintain the E-Commerce site on a part time basis. Strategic risks associated with an E-Commerce site were only considered by the managing director as he had total control over the development of the ECommerce site and the other key stakeholders involvement was directed development and maintenance. The following comment by the managing director indicates that he was driving the E-commerce system development and adoption of new web technologies.

"Yes they serve us. I don't really think of them as stakeholders we use self employed individuals rather than corporations, I don't think I wouldn't call them stakeholders. We would certainly listen to their advise but they wouldn't give us" (D1:T152:155).

This may be both a strength and a weakness given that his perceptions of strategic risk will be governed by his particular frames of reference. As with all businesses, legal risks need to be addressed but the flower industry is not a highly regulated industry, and only normal legal issues associated with doing business needed to be addressed. Increased liquidity was not an applicable in Case D's industry and narrowing of margins was only of concern to the manager director. As was noted in Case C, the narrowing of margins had actually occurred in the traditional business model of Case D. The move to an E-Commerce presence was an attempt to remain viable in the long term in an industry that had been impacted on and rationalised by the advent of the Internet. The following comment by the managing director emphasises that he considered that the move toward an E-commerce presence was critical to the long term survival in the industry.

"Well we went on the Web in 1994 business started in 92 with the Web as we know it or the Web itself actually ..... We visited America in 94 and heard about the internet there and the forecast was that in our industry, our American counterpart said they expected $30 \%$ of their business to be lost to the Web inside 5 years and they were pretty accurate actually so we were both excited and depressed by that and put all our florists on the web and as far as I know I think we were the first florist relay service in the world to have a website and have all our florists on the website" (C1:T10:20). 


\section{CONCLUSIONS}

This paper seeks to explore the relationship between E-Commerce and a psychological construct. It does not seek to make definitive statements; rather, it explores potentialities. There appear to be some betweenorganisation differences in terms of the perceived risk of E-commerce. While it could be argued that this is simply a reflection of the different industries in which these organisations operate and the different imperatives peculiar to those industries, it could equally be argued that this is a strong indicator of the framing heuristic in action. While it may very well be true that a corporation needs to pay heed to the requirements of its particular markets, there is some evidence to suggest that this focus can lead the corporation to ignore more general risks that apply across the broader spectrum of E-Commerce activities.

We were initially surprised at the extent to which all four cases were aligned with the financial institution risk perception model suggested by APRA. We were interested to see that the non-banking companies recognised some of the risks which are apparently more significant in a banking environment. Overall, the APRA model does seem to apply to a variety of contexts On closer analysis, this is perhaps more of a weakness than a strength. The factors are simply too general. Once people began speaking about individual concerns, the general factors began to narrow into highly-focused, specific concerns. Thus, one individual was indeed concerned with operational issues but his concern was highly focused on the technical capabilities of search engines. This concern emerged nowhere else.

The two smaller companies also come across as innovative and sensitive to the business environment whereas the financial institutions rely on the strength of their procedures. They believe that the traditional SDLC approach to engineering systems is adaptable to development for the Internet. Indeed, in their opinion it is the best way to address concerns regarding security. This issue is beyond the scope of this paper but it must be mentioned that there is some debate about the best way in which to conduct development for the Internet Some would favour RAD and prototyping approaches in environments which someone like Peters (1987) would describe as unpredictable and chaotic, requiring rapid and continuous adaptation from the corporation.

The intra-organisational differences are somewhat more striking. There is evidence to indicate that different organisational levels and functions view E-Commerce in divergent ways. There is also evidence that the us and them 'attitude is as strong as ever, and herein lies the most interesting finding of the study. In two of the organisations, management complained 
that their IT departments were not delivering. I.T departments are referred to as 'whingers' who offer excuses and not solutions. These managers speak about the need for speed, customer focus, ongoing redevelopment and customisation. To these people, the key risks relate to lack of speed and not meeting the market. Developers, on the other hand, seem to focus on traditional techniques and procedures as the best tools to manage risk. They complain that management expects too much and does not understand what they do. One developer focuses on the way in which detailed change management helps in efforts to control risk.

It seems to us that these differences in perception is one of the reasons many E-Commerce projects have run into trouble. On the one hand, management does not understand the level of complexity of the technology or its rapid pace of change. On the other hand, I.T. developers do not understand that margins are under pressure and time is of the essence. While it is true that traditional systems development has not been free of the same differences of opinion that we see now, it could be argued that software engineering approaches made the whole development process more predictable and we cannot now blame I.T. people for wanting to use these techniques. The problem is: are these techniques applicable to today's requirements?

We suggest that our case study supports the following general arguments:

1. People continue to view E-Commerce systems development as uncertain and / or risky. Indeed, even when they are speaking about E-Commerce in general terms the topic of risk emerges in a variety of guises.

2. People from different areas and levels of the corporations studied did indeed view the process and goals of E-Commerce system development in different ways. Of course, some of these differences can be explained in terms of the fact that the people involved occupied different occupational roles. The framing heuristic has a wide influence, however, and encompasses perceived occupational role and distinctive corporate influences.

3. Although there was a relative degree of convergence in terms of interorganisational risk perceptions, this only applied when the risks themselves were framed in the most general of terms. Dominant concerns tended to be much more specific and varied widely.

4. In at least two organisations, people who filled boundary-spanning roles were highly focused on innovation, rapid adaptation and the external environment whereas those involved in development were focused on control, security and measured change.

It may be that chaotic development exists within apparently structured organisations and procedures due to the different perceptual frames of references that underpin the thinking of key stakeholders. Of course, it is 
possible that a wide variety of opinions and perceptions make for good ECommerce systems development due to some undefined symbiotic element. It is our experience, however, that when a wide variety of perceptions exist, one set comes to dominate. If that set is bound by a paradigm out of touch with commercial reality, the consequences are likely to be unfavourable.

We also believe the cases suggest that the uncertain and complex world of E-Commerce systems development does indeed make people withdraw into their own limited specialist worlds where they feel secure in their perceived expertise and view people from other parts of the organisation with suspicion.

It would appear that a challenge, in the face of the increasing complexity and uncertainty of E-Commerce systems, is to align the perceptions of key stakeholders towards risk, process and corporate exigencies in order to have a coherent and focused E-Commerce system development approach. More work is required in this area of research and current information systems development approaches do not acknowledge potential impact and significance of differing frames of reference in the development of information systems. In particular, development of E-Commerce systems exasperate the problem given that key stakeholders are dealing with uncertainty and complexity using frames of reference which may or may not be appropriate.

\section{REFERENCES}

APRA Insight 2001, Prudential Issues in Electronic Commerce, Ist Quarter 2001

Angehrn, A and Meyer, A (1997) Developing mature Internet strategies, Information Systems Management, Vol. 14 No. 3, pp. 37-43.

Galliers, R. (1994) Choosing Information Systems Research Approaches, in:

G. R. Henley (Ed) Information Systems Research: Issues, Methods and Practical Guidelines, Alfred Walker, pp. 144-162 .

Douglas, M. And Wildavsky, A. (1982) How can we know the risks we face? Risk Analysis 2

Drucker, P.F. (1988) The Coming of the New Organisation. Harvard Business Review, JanFeb

Earl, M. (1997) Management in the Information Era. cited in: Bickerstaffe, G. (ed.) Mastering Management: Pitman:London

Gable, G (1994) Integrating case study and survey methods: An example in information systems, European Journal of Information Systems, vol. 3, No 2, pp. 112-126.

Gue Henno (1995) The end of the Nation State. Minneapolis: Unviversity of Minnesota Press Handy, C. The Age of Unreason. Business Books:London

Kahneman, D. And Tversky, A. (1974) Judgement of under uncertainty: Heuristics and Biases, Science, No 185, September

Marchand, D. And Horton, W. Infotrends. John Wiley and Sons: London

Peters, T. (1987) Thriving on Chaos. Pan: London 
Reichardt, C. (1992) The Fallibility of our Judgements. Evaluation Practice volume 3 Russo, E. And Shoemaker, P.J. (1991) Confident Decision Making. Piatkus: London

Russo, E. And Shoemaker, P.J. (1990) The Overconfidence Quiz. Harvard Business Review, September

Russo, E. And Shoemaker, P.J. (1992) Managing Overconfidence. Sloan Management Review, Winter

Simon, H.A. (1976) Administrative Behaviour. MacMillan: New York

Smart, C. and Vertinsky, I. (1984) Strategy and the Environment: A Study of Corporate Responses to Crises. Strategic Management Journal, July-September

Walsh, J.P. (1988) Selectivity and Selective Perception. Academy of Management Journal, Volume 31 number 4

Webber, R. (1997) Modern Imperatives. cited in: Bickerstaffe, G. (ed.) Mastering Management: Pitman:London

Wiseman, C. (1988) Strategic Information Systems. Irwin: Illinois

Yin, R. K. (1994) Case Study Research - Design and Methods (Thousand Oaks, California, Sage). 